\title{
A new approach to recruitment overfishing diagnosis based on fish condition from survey data
}

\author{
Francesc Ordines ${ }^{1}$, Josep Lloret ${ }^{2}$, Pilar Tugores ${ }^{1}$, Chiara Manfredi ${ }^{3}$, Beatriz Guijarro ${ }^{1}$, \\ Angélique Jadaud ${ }^{4}$, Cristina Porcu ${ }^{5}$, Luis Gil de Sola ${ }^{6}$, Roberto Carlucci ${ }^{7}$, Marina Sartini ${ }^{8}$, \\ Igor Isajlović ${ }^{9}$, Enric Massutí ${ }^{1}$

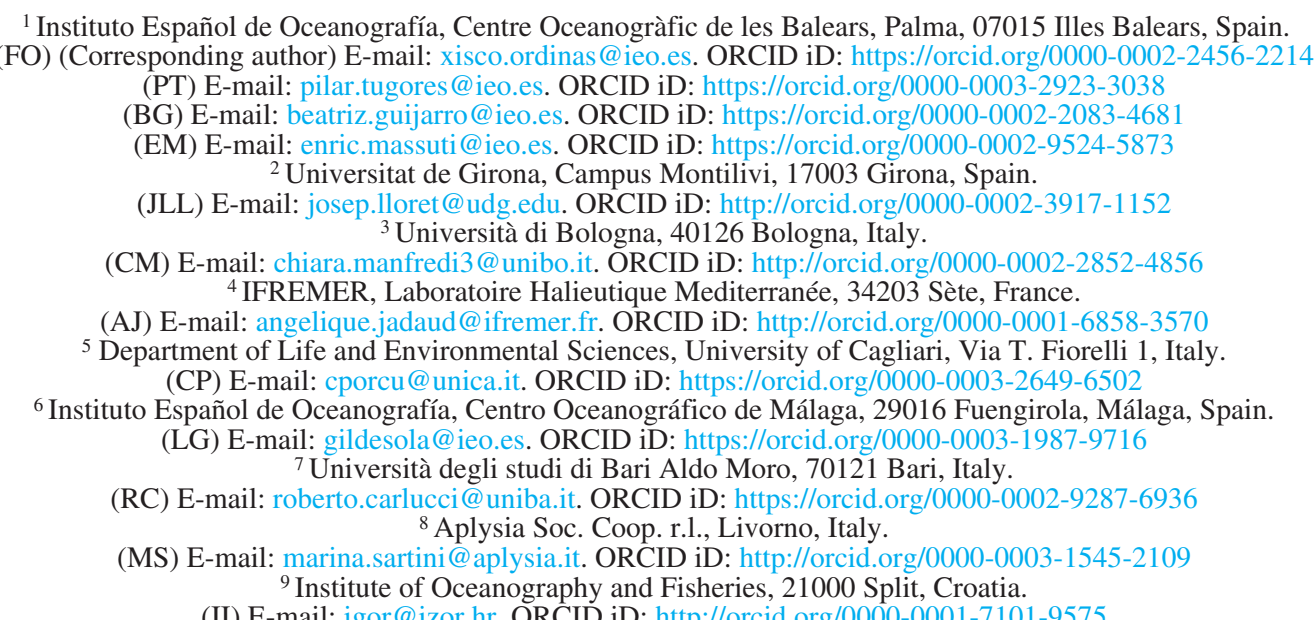

Summary: A new approach to recruitment overfishing diagnosis is presented. We hypothesize that condition of recruits should increase when recruitment failures are caused by fishing activity. This would be a consequence of the increase in trophic resource availability, because the population is smaller than that which the ecosystem could support. Temporal series of hake recruit condition were calculated from MEDITS survey data collected in Mediterranean geographical sub-areas (GSAs) 1, 6, 17 and 19 from 1994 to 2015. Multiple linear regressions were used to analyse the relationship between mean annual condition and abundance of recruits and climatic indices in each GSA. Significant correlations were only detected in GSA 6, where $69 \%$ of condition variability was explained by the negative correlation with recruit abundance, and with two climatic indices, the Western Mediterranean Oscillation and the standardized air temperature anomaly at surface from the Gulf of Lions. Despite the differences in recruit abundance among GSAs, their mean annual condition oscillated around the same basal value during most of the time series, pointing to density-dependent mortality rates as an important mechanism stabilizing hake recruitment to levels close to the carrying capacity when populations do not suffer recruitment overfishing. This pattern changed when the decreasing recruit abundance trend drove GSA 6 condition values persistently above those of the rest of the GSAs. According to our hypothesis, hake in GSA 6 is in recruitment overfishing.

Keywords: Merluccius merluccius; fishery; recruits; condition index; recruitment overfishing; MEDITS survey.

Una nueva aproximación al diagnóstico de la sobrepesca de reclutamiento basada en la condición de los recursos a partir de datos de campaña

Resumen: Este trabajo presenta una nueva aproximación al diagnóstico de la sobrepesca de reclutamiento. Nuestra hipótesis consiste en que la condición de los reclutas debe aumentar cuando suceden fallos en el reclutamiento debidos a la actividad pesquera. Esto sería una consecuencia del incremento en la disponibilidad de recursos tróficos debido a que la población es más reducida que la que el ecosistema podría soportar. Se calcularon series temporales de condición de reclutas de merluza a partir de datos recogidos en las campañas MEDITS en las sub-áreas geográficas (GSAs) 1, 6, 17 y 19 entre los años 1994 y 2015. Se utilizó la regresión lineal múltiple para analizar la relación entre la condición media anual y la abundancia de reclutas e índices climáticos en cada GSA. Solo se detectaron correlaciones significativas en la GSA 6, dónde el 69\% de la variabilidad en la condición se explica por la correlación negativa con la abundancia de reclutas, y con dos índices climáticos, la Oscilación del Mediterráneo Occidental y la anomalía estandarizada de la temperatura del aire en superficie en el Golfo de León. A pesar de las diferencias en la abundancia de reclutas entre GSAs, su condición anual media osciló alrededor de un mismo valor basal durante la mayor parte de la serie temporal, sugiriendo que las tasas de mortalidad denso-dependiente son 


\begin{abstract}
un mecanismo importante para la estabilización del reclutamiento de merluza en niveles próximos a la capacidad de carga cuando las poblaciones no sufren sobrepesca de reclutamiento. Este patrón cambió cuando la tendencia decreciente de la abundancia de reclutas elevó los valores de condición en la GSA 6 por encima de los del resto de GSAs de forma persistente. De acuerdo con nuestra hipótesis, la merluza de la GSA 6 se encuentra en sobrepesca de reclutamiento.
\end{abstract}

Palabras clave: Merluccius merluccius; pesquería; reclutas; índice de condición; sobrepesca de reclutamiento; campaña MEDITS.

Citation/Cómo citar este artículo: Ordines F., Lloret J., Tugores P., Manfredi C., Guijarro B., Jadaud A., Porcu C., Gil de Sola L., Carlucci R., Sartini M., Isajlović I., Massutí E. 2019. A new approach to recruitment overfishing diagnosis based on fish condition from survey data. Sci. Mar. 83S1: 223-233. https://doi.org/10.3989/scimar.04950.03A

Editor: B. Mérigot.

Received: January 21, 2019. Accepted: May 10, 2019. Published: July 31, 2019.

Copyright: ( 2019 CSIC. This is an open-access article distributed under the terms of the Creative Commons Attribution 4.0 International (CC BY 4.0) License.

\section{INTRODUCTION}

The Food and Agriculture Organization adopted the definition of recruitment overfishing in Restrepo (1999): "A situation in which the rate of fishing is (or has been) such that annual recruitment to the exploitable stock has become significantly reduced. The situation is characterized by a greatly reduced spawning stock, a decreasing proportion of older fish in the catch, and generally very low recruitment year after year. If prolonged, recruitment overfishing can lead to stock collapse, particularly under unfavourable environmental conditions". This definition takes into account most of the aspects considered in previous definitions of this type of overfishing [see Sainsbury and Polacheck (1993) and references therein].

According to Walters and Maguire (1996), the causes of one of the most renowned collapses in fisheries, that of the northern cod, were an overestimation of the stock abundance and failure to recognize the recruitment overfishing, even when a declining pattern in recruitment paired with a strong stock-recruitment correlation had been observed. Recruitment decline was attributed to unfavourable oceanographic conditions (Walters and Maguire 1996). In fact, a recruitment failure has two main causes: i) low egg production due to a reduced spawning stock and/or a low spawning activity of adults; and/or ii) a high mortality in the early life stages before recruitment to fishing stocks, which may be related to unfavourable oceanographic conditions (Watanabe et al. 1995). The two causes may occur together and it may be difficult to discern one from the other. However, emphasizing the importance of the environmental influence on recruitment variability may lead stock assessments to ignore an underlying recruitment overfishing (Walters and Maguire 1996).

There have been attempts to search for useful thresholds to determine recruitment overfishing based on biomass reference levels (Sissenwine and Shepherd 1987, Myers et al. 1994). However, the use of reference points to diagnose recruitment overfishing is not commonly taken into account in most fisheries assessment bodies (but see the stock status classification system from the Australian government, https://www. fish.gov.au/About), although for some species reference points have been proposed [see e.g. Nakatsuka et al. (2017) for Pacific Bluefin tuna]. This is comprehensible because of the uncertainty regarding the causes underlying a recruitment failure and analytical difficulties such as relating the definition of recruitment overfishing to fishing mortality (Sissenwine and Shepherd 1987), the intrinsic difficulty of estimating reliable absolute abundances of fish stocks (Hilborn 2002), including those of spawners and recruits, and the exclusion from classical stock-recruitment models of important factors for recruitment such as the influence of environmental conditions and the effects of the size and physiological condition of spawners on egg production and quality of the offspring (Lloret et al. 2014, Domínguez 2006).

Most definitions of overfishing are related in some way to maximum sustainable yield (MSY) (Hilborn and Stokes 2010). The assessment of Mediterranean fish stocks is no exception, and the General Fisheries Commission for the Mediterranean (GFCM) and the Scientific, Technical and Economic Committee for Fisheries (STECF), in line with the Common Fisheries Policy, have adopted the fishing mortality producing the MSY $\left(\mathrm{F}_{\mathrm{MSY}}\right)$, or its proxy $\mathrm{F}_{0.1}$, as a reference point (GFCM 2014, STECF 2015), considering that any fishing mortality beyond $\mathrm{F}_{\mathrm{MSY}}$ indicates an overfished stock, without specifying growth or recruitment overfishing.

In the Mediterranean Sea, the assessment of fish stocks is based on geographical sub-areas (GSAs, Resolution GFCM/31/2007/2). In all GSAs where the European hake, Merluccius merluccius (Linnaeus, 1758), is currently assessed, the populations have been diagnosed as overexploited (GFCM 2017, STECF 2017, 2018). Though this situation has not changed for many years, and in some areas (e.g. eastern Iberian Peninsula, GSA 6, and Gulf of Lions, GSA 7; GFCM 2017) spawning stock biomass and recruitment show a sharp declining trend, the possibility that these populations are affected by recruitment overfishing has not been explored.

"Fish condition" is a widely used term referring to the overall physiological status or health of an individual (Lloret et al. 2014). Among the most important effects of poor fish condition are increased natural mortality, suppression of reproduction, late maturity and low fecundity, and low larval and juvenile survival 
(Dutil and Lambert 2000, Morgan 2004, Skjæraasen et al. 2012). Moreover, a decrease in the productivity of fish stocks, as well as a higher vulnerability to human perturbations, has also been revealed (Dutil and Lambert 2000). Particularly for the hake, the success and individual condition of recruitment shows a strong dependence on environmental conditions, productivity and the availability of feeding resources (Sánchez et al. 2003, Abella et al. 2008, Bartolino et al. 2008).

In the present study we aim to explore a new approach to the assessment of recruitment overfishing based on condition of hake recruits collected during the Mediterranean International Trawl Surveys (MEDITS) since 1994. We hypothesize that recruit condition should increase when failures in recruitment occur due to fishing activity. This increase in condition must be mediated by a higher availability of trophic resources for recruits, as a consequence of a lower number of individuals: in other words, recruit abundance is reduced below the carrying capacity of the ecosystem. However, the hypothesized increase in condition could be masked by the effect of environmental variability, and more particularly by variations in climatic conditions, which have already been reported to influence hake recruitment (Hidalgo et al. 2008, Massutí et al. 2008). To explore our hypothesis, we analysed the temporal series of weight-at-length data of recruits, normally used as a proxy of fish condition (Lloret et al. 2014), and its relationship with hake recruit abundance and climatic indices in different areas of the Mediterranean Sea.

\section{MATERIALS AND METHODS}

\section{Sampling}

Data and samples were collected during the annual MEDITS surveys from 1994 to 2015. The sampling gear used, the bottom trawl GOC73 and the sampling scheme applied in these surveys are described in detail by Bertrand et al. (2002). This gear shows high efficiency in the catch of demersal species, including juveniles of M. merluccius (Dremière et al. 1999, Fiorentini et al. 1999). The sampling stations studied cover a depth range of 10 to $800 \mathrm{~m}$ along the western and central Mediterranean Sea GSAs 1, 2, 5, 6, 7, 8, 9, 10, 11, 16, 17, 18 and 19 (Fig. 1). The experimental hauls were conducted during daylight hours, with durations of 30 to 60 minutes, depending on the depth stratum. The towing speed was about 3 knots and the net's arrival at and departure from the bottom, as well as its horizontal and vertical openings (usually ranging from 16 to $20 \mathrm{~m}$ and 2.5 to $3.2 \mathrm{~m}$, respectively) were measured in real time using acoustic systems attached to the gear. The geographical position of the boat at the beginning of the effective fishing at the bottom was recorded by a GPS system. In each sample, abundance, biomass and length frequency of the species were determined and standardized to one square $\mathrm{km}$ using the distance covered and the horizontal opening in each haul. Biological samplings of hake were also done on a sampling station basis. These samplings, which included individual sex, maturity stage, total length (TL,

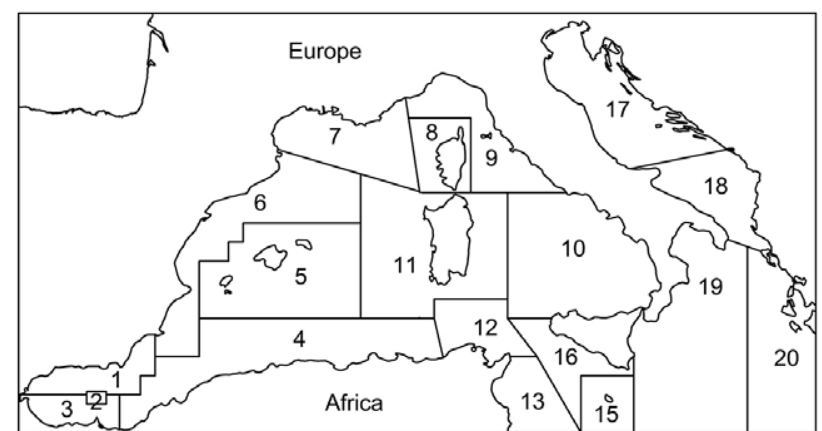

Fig. 1. - Map showing the GFCM geographical sub-areas in the western and central Mediterranean Sea.

to the half $\mathrm{cm}$ ) and total weight (W, to the nearest 0.1 g) of representative samples from every haul in which this species appeared began to be performed in different years depending on the GSA.

The geographical analyses, which took into account all the above-mentioned GSAs, involved a total of 4252 sampling hauls performed between 2012 and 2015, the period in which hake biological data is available for all GSAs in the study region. For the temporal series analyses, only the GSAs with the longest time series of hake biological data were considered: 1, 6, 19 and the Italian side of 17. In the MEDITS programme, the sampling of individual biological parameters has been compulsory for hake in all GSAs only since 2012. However, for these four areas the biological sampling of hake has been available since the beginning of the MEDITS surveys: 1994 in GSA 17 and one year later (1995) in the rest. A total of 6685 sampling hauls (GSA1: 880; GSA6: 1690; GSA17 (Italy): 2548; GSA19: 1567) and 86171 biological samplings of hake recruits were taken into account for the time series analyses.

\section{Recruit abundance and somatic condition}

The standardized abundance (ind. $\mathrm{km}^{-2}$ ) of hake recruits (0-age group) was calculated by setting a threshold of $18 \mathrm{~cm} \mathrm{TL}$, according to the total length at the end of the age- 0 class reported in the growth model for sexes combined by Mellon-Duval et al. (2009). Then the sum of all individuals below $18 \mathrm{~cm}$ TL was divided by the area swept in each haul.

In order to obtain the mean annual abundance of recruits for each GSA, their depth distribution was analysed and depths at which recruits were not usually present were excluded. The depth range included individuals from 46 to $305 \mathrm{~m}$ in GSAs 1 and 6; individuals from 25 to $300 \mathrm{~m}$ in GSA 17 (Italy); and individuals from 47 to $280 \mathrm{~m}$ in GSA 19. In all cases, the number of recruits retained for the analyses in each GSA within the specified bathymetric ranges accounted for more than $99 \%$ of the whole number of recruits. In the case of GSA 17 , where the distribution of recruits was clearly located at the southern part of this GSA, a further restriction was applied when calculating their mean abundance, and only those samples located below latitude $44^{\circ} \mathrm{N}$ were considered. In this GSA, more than $98.5 \%$ of recruits were retained for the analyses. 
Size-independent measures of individual somatic condition (SC) of recruits were calculated. First, the log-transformed linear relationship between $\mathrm{W}$ and TL was calculated in order to obtain the predicted $\log (\mathrm{W})$ by sex. Differences in the log-transformed W-TL relationships between sexes were tested by applying analysis of covariance (ANCOVA) to the log-transformed data. Because no difference between sexes was found, logtransformed W-TL relationships were calculated for the whole population. Then, the residuals were calculated as the difference between the log-transformed observed and predicted $\mathrm{W}$, and standardized by dividing each by the standard deviation of their predicted $\log (\mathrm{W})$ values. An individual that is lighter than the predicted weight for its length from the regression equation will have a negative residual, and is assumed to be in poorer condition than an individual that is heavier than the predicted weight for its length, which will have a positive residual (Hayes and Shonkwiler 2001).

Due to the minimum precision of the weight measures, $0.1 \mathrm{~g}$, the $\mathrm{SC}$ analyses were restricted to recruits $>8.5 \mathrm{~cm}$. The $\pm 0.1 \mathrm{~g}$ error due to scale precision thus represents less than $1 \%$ of the theoretical weight of the smallest individuals. When the analyses of SC involved more than one GSA, the individual SC was calculated considering a W-TL relationship in which all the individuals sampled in all the GSAs involved were taken into account. This allowed comparable values of SC among GSAs to be obtained.

In the calculation of the mean annual values of SC by GSA the individuals taken into account followed the same bathymetric and geographical restrictions applied to the calculation of the mean annual abundance of recruits.

\section{General geographical pattern of $\mathrm{SC}$ and recruit abundance}

The main objective of this analysis is to frame the different areas studied in the Mediterranean context. Therefore, the calculation of SC and the standardized recruit abundance was restricted to the period 20122015 , in which the biological sampling of hake was available for all GSAs. The mean SC per haul was finally plotted in maps, excluding hauls in which $<5$ recruits were sampled.

In the case of recruit abundance, the higher number of samples allowed us to use a generalized additive model (GAM) to predict the abundance values in the whole study area by year. In the model, the dependent variable was the log-transformed standardized abundance of recruits per haul, whereas the explanatory variables were year included as a factor, and the smoothed effects of depth and position of the haul (latitude and longitude) by year. A Gaussian family residual distribution was applied after checking model residuals. The GAM was performed using the $m g c v$ package (Wood 2006) in R software (R Core Team 2017).

\section{Climatic indices}

Four climatic indices that have been related to Mediterranean meteorological and circulation events were used to analyse possible relationships with annual variation of hake condition. Two large-scale climatic indices, the Northwestern Atlantic Oscillation (NAOi) index and the Mediterranean Oscillation Index (MOi), and two regional climatic indices, the Western Mediterranean Oscillation index (WeMOi) and the IDEA index (IDEAi), were used.

NAOi, MOi and WeMOi are calculated from atmospheric pressure gradients in the Atlantic Ocean and/or the Mediterranean Sea. Monthly mean NAOi was obtained from the NOAA National Weather Service, Climate Prediction Center (http://www.cpc.ncep. noaa.gov/products/precip/CWlink/pna/nao.shtml). This index is estimated with a rotated principal component analysis applied on the monthly standardized $500-\mathrm{mb}$ height anomalies in the Atlantic for the region comprised between $20^{\circ} \mathrm{N}$ and $90^{\circ} \mathrm{N}$ and between January 1950 and December 2000 (Barnston and Livezey 1987). The MOi is the normalized pressure difference between Gibraltar's Northern Frontier and Lod Airport in Israel (Palutikof et al. 2003). MOi data were obtained from the Climatic Research Unit of the University of East Anglia (https://crudata.uea.ac.uk/cru/data/moi/). The WeMOi is a regional index that estimates the difference between the barometric time series in Padua (northern Italy) and San Fernando (Cádiz) in the southwest of Spain (López-Bustins 2007). Monthly mean WeMOi was obtained from the Climatology Group of the University of Barcelona (http://www.ub.edu/gc/ wemo/).

The IDEAi is a meso-scale index related to the temperature in the northwestern basin of the Mediterranean. This index measures the standardized air temperature anomaly at surface $(1000 \mathrm{hPa})$ from the Gulf of Lions, collected with a daily resolution and averaged for the winter months (Monserrat et al. 2008). According to these authors, IDEAi is related to the inter-annual variability of intermediate water formation, as well as to the seasonal surface circulation and primary production patterns in the northwestern Mediterranean.

\section{Trends in SC, recruit abundance and climatic indices and their relationship}

Linear regression analysis was used to explore for temporal trends in time series of SC, recruit abundance and climatic indices in the GSAs where these data were available from 1995 to 2015 (GSAs 1, 6 and 19) and from 1994 to 2015 (GSA 17).

An overall SC mean $\pm 95 \%$ confidence interval (CI95\%) was calculated taking into account the period of the time series of SC in which the trend of any GSA had driven its values consistently above (or below) the values of the rest of the GSAs. The CI95\% was used as a threshold to distinguish the values of a particular GSA that were significantly above (or below) the overall mean.

Multiple linear regression analysis was used to analyse the relationship between SC and recruit abundance and climate variability throughout the MEDITS time series. Therefore, only those GSAs with the longest time series of biological data for hake could be taken into account: GSAs 1, 6, 17 (Italy) and 19. The de- 
pendent variable was the mean annual SC of recruits in each GSA. The explanatory variables tested included the mean annual standardized abundance of recruits, and the main climatic indices potentially affecting the oceanographic condition in each area (NAOi, MOi and WeMOi were included in the models of all GSAs, whereas IDEA was only added to GSA 6 models, due to its geographic specificity). The values of NAOi, MOi and WeMOi consisted of the average of the monthly values of the 12 months previous to the start of MEDITS surveys, whereas the IDEAi value was used directly as it is only recorded during the winter. The explanatory variables were checked for collinearity. Significant correlation (positive) was found between NAOi and MOi (0.52) and WeMOi and MOi (0.43), and alternate models including/excluding NAOi and MOi were tested. A lag of 0 and 1 year was used for climatic indices aiming to detect delayed effects of climate variability on the SC of recruits. Residuals of the models were tested for autocorrelation, which was not detected in any case. Multiple linear regressions and autocorrelation analyses were performed using the $\mathrm{R}$ software (R Core Team 2017). The beta standardized coefficient of each explanatory variable was calculated using the R package lm.beta (Behrendt 2014).

\section{RESULTS}

\section{General geographic patterns of SC and recruit abundance}

The maps representing the mean SC per haul for the years 2012 to 2015 show high variability depending on the year for all GSAs (Fig. 2). However, an aspect that
Table 1. - Percentage of hauls showing a mean positive value of somatic condition by geographical sub-area (GSA) and year. Between brackets, the total number of hauls analysed per year (those with at least SC data for five recruits). The mean \pm standard error for the total number of hauls in each GSA is also presented.

\begin{tabular}{cccccc}
\hline \multirow{2}{*}{ GSA } & \multicolumn{5}{c}{ Year } \\
& 2012 & 2013 & 2014 & 2015 & Total \\
\hline 6 & $86.9(61)$ & $89.6(67)$ & $97.8(45)$ & $88.9(63)$ & $90.3 \pm 2.4$ \\
7 & $89.5(19)$ & $77.8(9)$ & $69.2(13)$ & $75(16)$ & $78.9 \pm 4.3$ \\
5 & $64.3(14)$ & $91.7(12)$ & $75(16)$ & $75(16)$ & $75.9 \pm 5.7$ \\
1 & $100(5)$ & $33.3(3)$ & $70(10)$ & $60(10)$ & $67.9 \pm 13.8$ \\
16 & $68.3(63)$ & $38.5(65)$ & $18.9(37)$ & $54.8(62)$ & $48 \pm 10.6$ \\
18 & $29.4(17)$ & $57.9(19)$ & $47.8(23)$ & $27.3(11)$ & $42.9 \pm 7.4$ \\
9 & $66.7(6)$ & $33.3(9)$ & $35.7(14)$ & $25(8)$ & $37.8 \pm 9.1$ \\
17 & $39.6(91)$ & $32.1(137)$ & $48.4(161)$ & $21.7(143)$ & $35.5 \pm 5.7$ \\
11 & $20(10)$ & $50(10)$ & $5.6(18)$ & $31.3(16)$ & $24.1 \pm 9.4$ \\
19 & $42.9(14)$ & $20(15)$ & $0(12)$ & $23.1(13)$ & $22.2 \pm 8.8$ \\
10 & $0(25)$ & $15.2(33)$ & $40(15)$ & $12.5(16)$ & $14.6 \pm 8.4$ \\
8 & $0(1)$ & $0(3)$ & $0(2)$ & $0(1)$ & $0 \pm 0$ \\
\hline
\end{tabular}

emerges throughout the four-year period is that the GSAs in the westernmost part of the study area have the highest proportion of hauls with positive mean SC values. This is very clear from the proportion referring to the total number of hauls in that period, which shows that in GSAs 6, 7, 5 and 1 the proportion of hauls with positive mean SC values was $90 \%, 79 \%, 76 \%$ and $68 \%$, respectively, whereas the rest of GSAs did not reach 50\%, with GSA 16 showing the highest values among them (48\%). In the case of GSA 8, none of the hauls showed a mean positive SC value (Table 1).

The GAM model applied to recruit abundance showed highly significant effects of both depth $(\mathrm{p}<0.0001)$ and location (latitude and longitude) by year $(\mathrm{p}<0.0001)$, as well as lower significant mean values in $2015(\mathrm{p}<0.05)$. The model explained $59.2 \%$ of the total deviance. The maps presenting the predicted
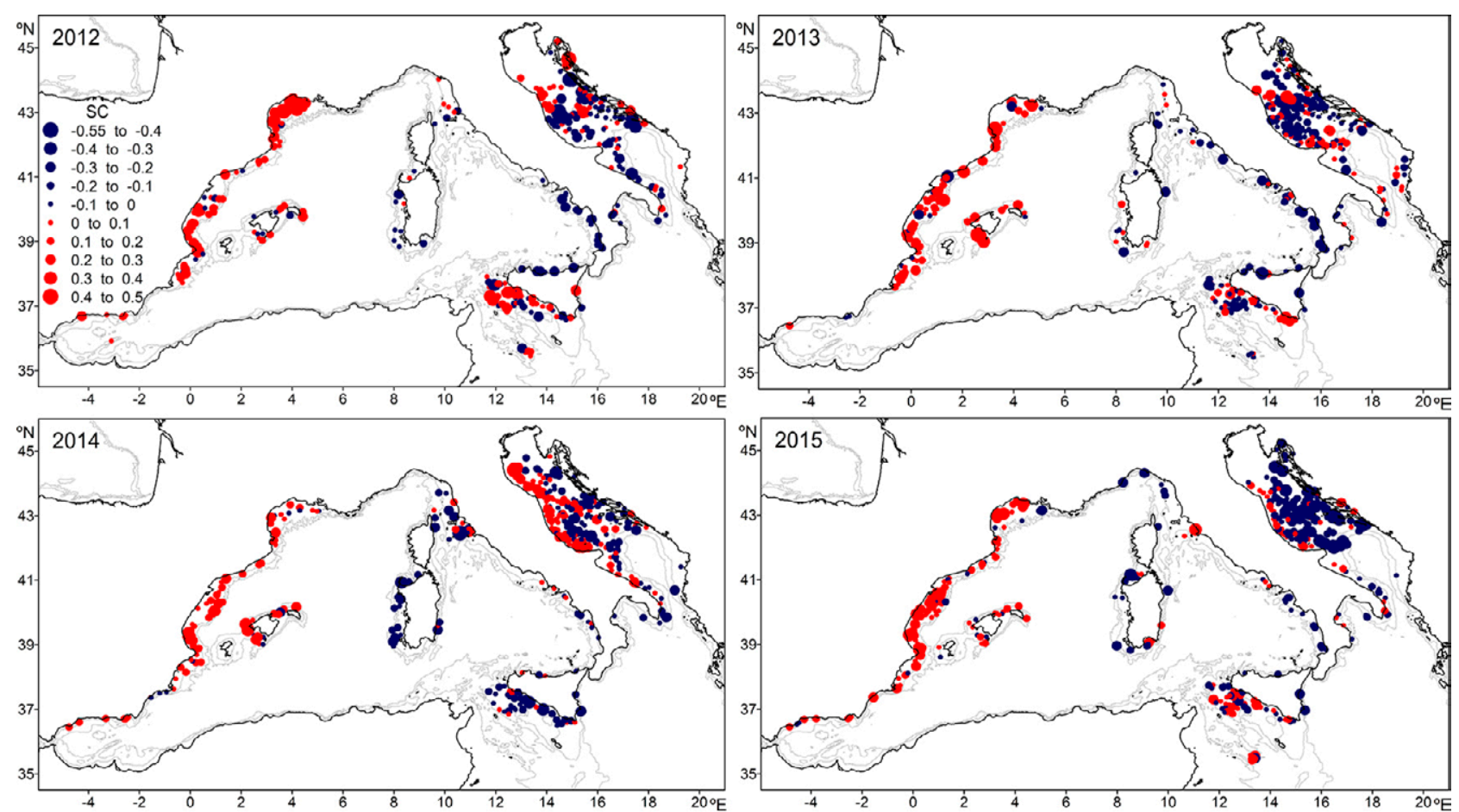

Fig. 2. - Annual maps from 2012 to 2015 showing the mean somatic condition (SC) of hake recruits at each MEDITS sampling station in the western and central Mediterranean Sea. Only hauls with at least five individuals were considered. 

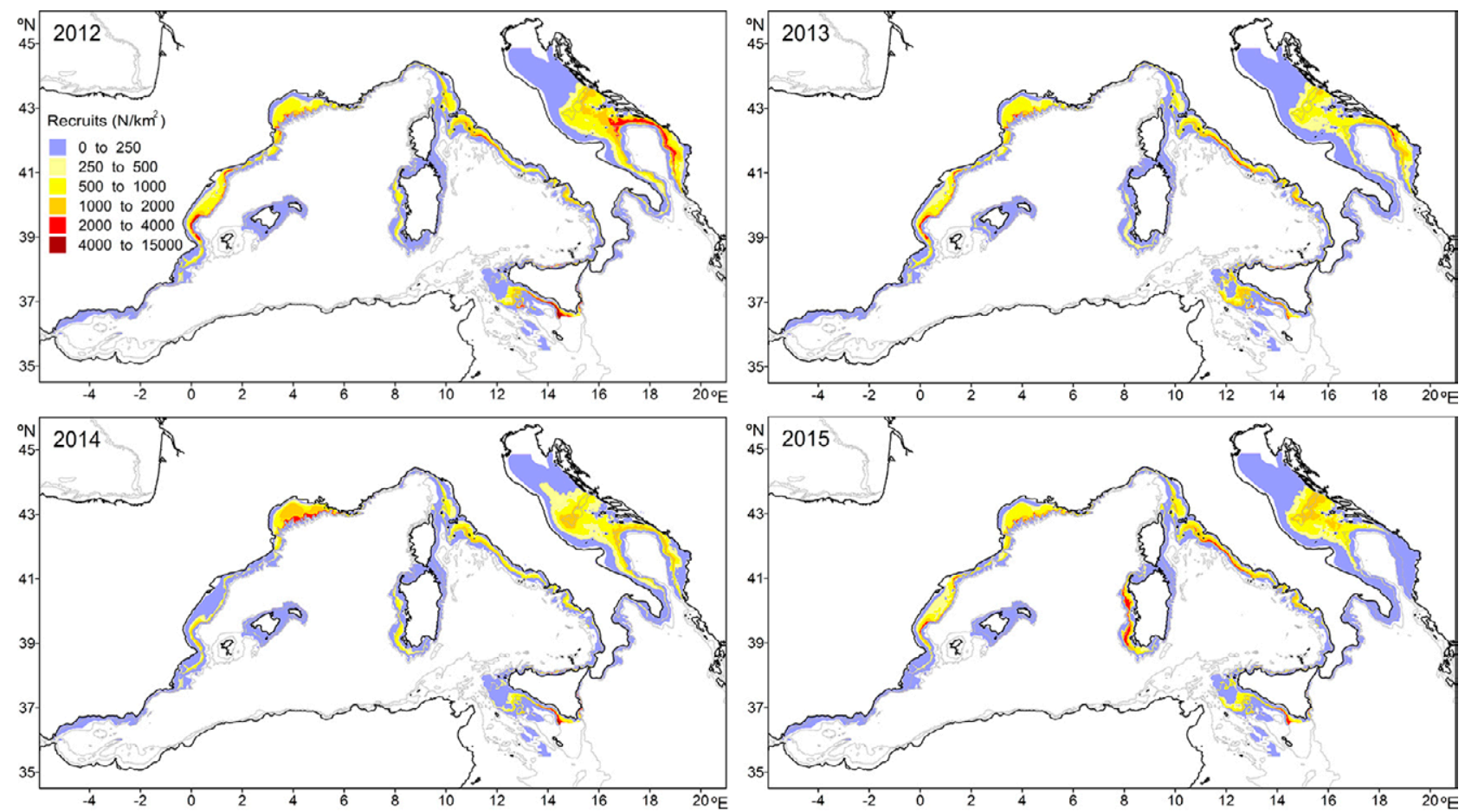

Fig. 3. - Annual maps from 2012 to 2015 showing the GAM model predictions of hake recruits abundance in the western and central Mediterranean Sea.

values of recruit abundance from the GAM model showed that the areas with the highest values appeared quite constant, being mainly located in the northeastern Iberian Peninsula (GSA 6), the Gulf of Lions (GSA 7), the northwestern Tyrrhenian Sea (GSA 9 and the north of GSA 10), western Sardinia (western GSA 11), southern Sicily (GSA 16) and central (Pomo Pit) and southern areas of the Adriatic Sea, in the south of GSA 17 and the north of GSA 18, respectively (Fig. 3). The lowest abundances were detected in the Alboran Sea (GSA 1), the Balearic Islands (GSA 5), eastern Sardinia (eastern GSA 11), the southern Italian Peninsula (GSA19 and the south of GSA 10) and the northern Adriatic Sea, in the north of GSA 17 (Fig. 3).

\section{Trends in SC, recruit abundance, climatic indices and their relationship}

The time series of SC in the four GSA's with the longest time series of hake biological samplings (GSAs 1, 6, 17 and 19) showed oscillations around zero (actual weight at length values equal to the expected weights at length), without a clear trend for GSA 1 and 19 during the whole time series (Fig. 4). A significant increasing trend was detected in the cases of GSA 6 $\left(\mathrm{p}<0.0001 ; \mathrm{R}^{2}=0.67\right)$ and GSA $17\left(\mathrm{p}<0.01 ; \mathrm{R}^{2}=0.43\right)$. This trend was steeper in GSA 6 from $2002(\mathrm{p}<0.0001$; $\left.\mathrm{R}^{2}=0.84\right)$ than for the whole data series (1995-2015). In this GSA the increasing trend drove mean annual values from 2009, except in 2010, to be persistently above the overall mean calculated during the previous period, taking into account all GSAs (i.e. above mean plus CI95\%=0.128) (Fig. 4). For GSA 17, the increasing trend detected was still significant with the removal of the extreme low value in $1995\left(\mathrm{p}<0.01 ; \mathrm{R}^{2}=0.39\right)$. In

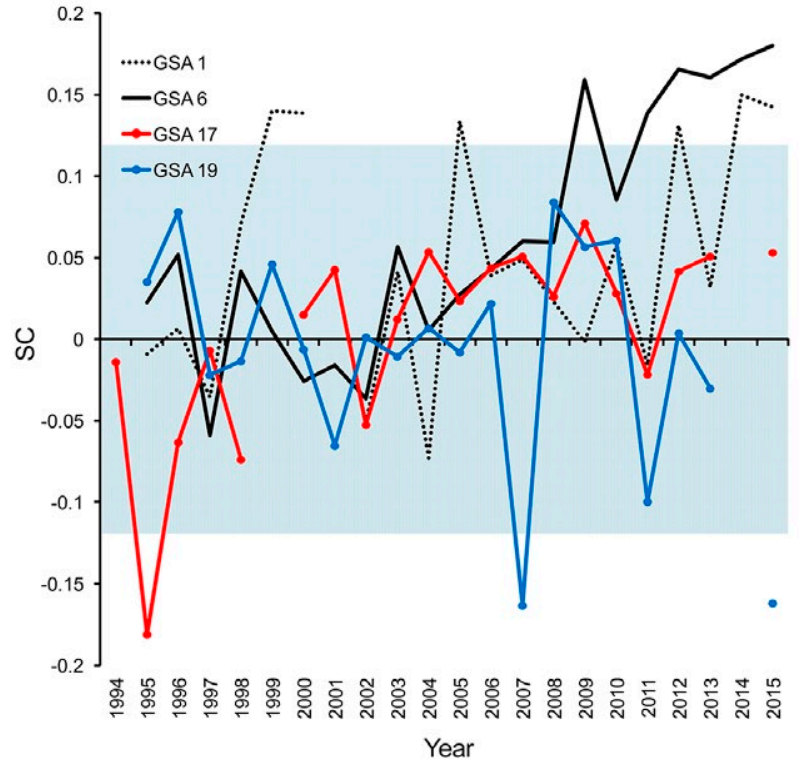

Fig. 4. - Trends of mean annual values of hake recruit somatic condition (SC) for GSAs 1, 6,17 and 19 during the whole period in which data were available. The $\pm 95 \%$ confidence interval of the overall mean is shown shaded in light blue.

this GSA, none of the mean annual values were significantly above the overall mean.

The time series of recruit abundance showed no significant trend in any GSA except GSA 6 (Fig. 5), in which a significant decreasing trend was detected $\left(\mathrm{p}<0.05 ; \mathrm{R}^{2}=0.15\right)$. Recruit abundance values were similar and minimum, not exceeding a mean of 1000 ind. $\mathrm{km}^{-2}$ in GSAs 1 and 19 until 2001. Afterwards, GSA 1 continued showing low values, only barely exceeding 1000 ind. $\mathrm{km}^{-2}$ in 2007 and 2014, whereas some peaks of recruit abundance ( $>2800$ ind. $\mathrm{km}^{-2}$ ) 


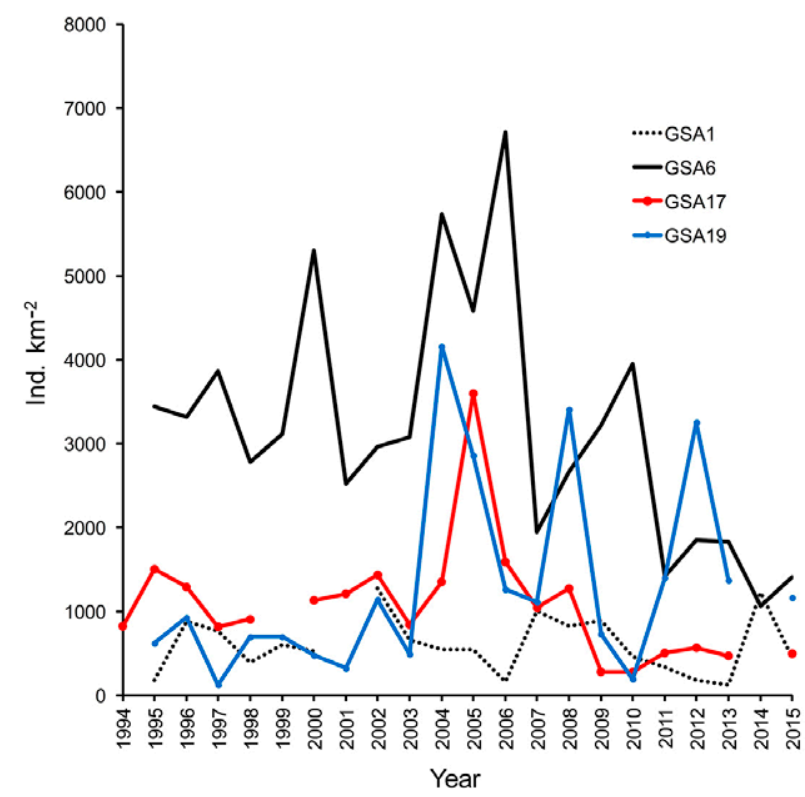

Fig. 5. - Trends of mean annual values of hake recruit abundance for GSAs 1, 6, 17 and 19 during the years in which somatic condition data were available.

were detected in GSA 19 in 2004, 2005, 2008 and 2012. In the case of GSA 17, recruit abundance ranged from 800 to 1500 ind. $\mathrm{km}^{-2}$ between 1994 and 2008, except in 2005 when a peak of 3500 ind. $\mathrm{km}^{-2}$ was detected. From 2009 to 2015 the values decreased and remained between 270 and 570 ind. $\mathrm{km}^{-2}$. The GSA 6 showed the highest values of all GSAs for all years except 2008 and 2012. In this GSA, a peak was detected in 2006 when recruit abundance reached 6716 ind. $\mathrm{km}^{-2}$. Values remained well above 2500 ind. $\mathrm{km}^{-2}$ during most of the years before this peak, while dur-

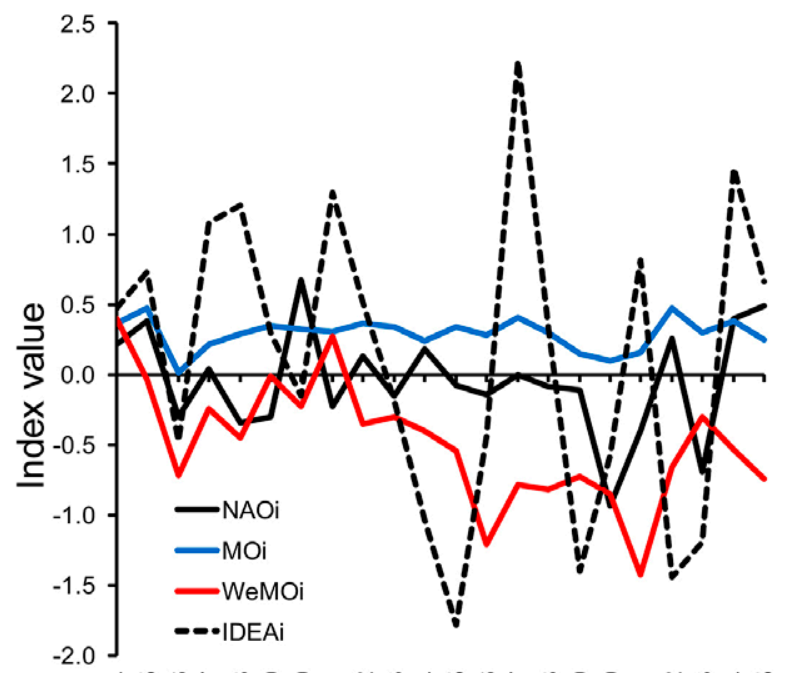

范 Year

Fig. 6. - Mean annual values of climatic indices used as explanatory variables in the multiple linear regression analyses. The represented values of NAOi, MOi and WeMOi consisted of the average monthly values of the 12 months previous to the start of the MEDITS surveys, whereas in the case of the IDEA index, only recorded during the winter, the mean of the winter months is represented.
Table 2. - Summary of multiple regression analysis results for somatic condition in GSA 6.

\begin{tabular}{lccccc}
\hline Explanatory variable & $\mathrm{a}-\mathrm{R}^{2}$ & $\beta$ & d.f. & $\mathrm{t}$ & $\mathrm{p}$ \\
\hline Recruits abundance & & -0.742 & & 5.430 & $<0.00001$ \\
WeMO & 0.691 & -0.445 & 17 & -3.541 & $<0.01$ \\
IDEA & & -0.449 & & -3.258 & $<0.01$ \\
\hline
\end{tabular}

ing most of the years after the peak recruit abundance did not reach 2000 ind. $\mathrm{km}^{-2}$, with a minimum for the whole time series in 2014 (1061 ind. $\mathrm{km}^{-2}$ ).

None of the climatic indices analysed showed any significant trend during the period 1994-2015 except WeMOi, which showed a decreasing trend $(\mathrm{p}<0.01$; $\mathrm{R}^{2}=0.37$; Fig. 6).

The multiple linear regression models showed no significant effect of recruit abundance or climatic indices on SC in GSAs 1, 17 and 19. Hence, the resulting model parameters are not tabled. On the other hand, a highly significant model $(\mathrm{p}<0.00001)$ was obtained in GSA 6 by including recruit abundance and WeMOi and IDEAi (Table 2). NAOi and MOi had no significant effect and were removed from the final model. The explanatory variables finally included in the model explained $69 \%$ of the variability of SC. There was a negative relationship between condition and density of hake recruits and IDEAi and WeMOi. The standardized coefficients estimated for the explanatory variables (beta coefficients) showed that the most important variable was mean recruit abundance, followed by IDEAi and WeMOi, with almost identical values of beta coefficients (Table 2).

\section{DISCUSSION}

The general pattern of European hake somatic condition in the western and central Mediterranean Sea for the last four years showed a large proportion of hauls with mean positive values in the westernmost areas. GSA 6 showed the highest proportions of hauls with mean positive values among all the GSAs analysed, over $90 \%$, showing the good condition status of hake inhabiting this area compared with GSA 8 and 10, where hake showed the lowest condition. However, the evolution of condition since 1994 in the GSAs with the longest time series of condition (GSA 1, 6, 17 and 19) showed that the current general pattern is a quite recent one, not extending much further back than the period in which condition data is available for all GSAs (2011-2015). This period is included within the period 2009-2015, in which the decreasing trend in the abundance of recruits in GSA 6 showed a major drop while the increasing trend in condition in GSA 6 became steeper and drove the mean annual values above the overall mean of the period 1994-2008 (the period in which none of the GSAs showed mean values persistently above the rest).

Our analyses of the variables affecting recruit condition did not include the spawning stock biomass (SSB) resulting from the virtual population analysis models shown in Figure 6, but rather the concurrent recruit abundance from MEDITS surveys which somehow is related to SSB. Although the variations in 
spawning stock are considered one of the major drivers in recruitment overfishing, the direct proportionality between egg production (and recruitment) and SSB is not always met, as in the European hake, for which the total egg production and quality largely depend on the age/size structure of the individuals in the spawning stock (Mehault et al. 2010). Whereas the variability in condition of hake in GSA 6 was explained to a large extent $(\sim 70 \%)$ by a negative correlation with the abundance of recruits and the IDEA and WeMO climatic indices, neither recruit abundance nor climate variability showed a significant effect on the mean annual condition of the rest of the GSAs. Although a significant increase in mean annual condition was detected in GSA 17, it must be stated that except for the extremely low value detected in 1995, the remaining years were not significantly different from the overall mean, hence oscillating within the general ranges for all GSAs. In GSA 17, the non-significant decreasing trend in recruit abundance was not important enough to significantly explain the trend in their condition, and/or co-occurring environmental variations masked its effect.

In general, during the period analysed, the condition in the four GSAs oscillated, with smaller or larger variations, above/below the mean, none of them showing persistent maximum or minimum values in comparison with the rest. This pattern in equilibrium ended in 2009, when GSA 6 clearly deviated from the mean due to its increasing trend in condition. In this area, the negative correlation detected between condition and recruit abundance, i.e. density-dependent condition, may be a response linked to the life history strategy of hake. Life history strategies were first defined on the basis of two end points, the $r$ and $k$ selections, which basically include species that produce the largest possible total number of offspring and those producing the offspring with the highest possible fitness, respectively (MacArthur and Wilson 1967, Adams 1980). Winemiller and Rose (1992) extended this $r$ and $k$ continuum, and defined a model with three end points that fitted better the strategies of fishes. In this model, a given species can fall anywhere in the space defined by the opportunistic (small, rapidly maturing and short-lived fishes), periodic (larger and highly fecund fishes with long life spans) and equilibrium (fishes of intermediate size that often exhibit parental care and produce relatively few, but large offspring) strategies. Species classification was simplified in Rose et al. (2001), who based it on egg diameter (larger or smaller than $2 \mathrm{~mm}$ ), as a proxy for the degree of parental investment in individual offspring and fecundity in number of eggs per female (higher or lower than 25000). Hake is a batch spawner with high fecundity and fast growth, which reaches maturity when individuals are 2-3 years old (Oliver 1993, Domínguez 2006, Mellon-Duval et al. 2009). According to El Habouz et al. (2011), the largest diameter of eggs in ripening hake females barely exceeds one $\mathrm{mm}$, whereas the batch fecundity ranges from around forty thousand to almost one million eggs (average around three hundred thousand) for the smaller and larger mature females, respectively. Recasens et al. (2008) gave estimations of batch fecundity for hake of between 17296 eggs for a female of $35 \mathrm{~cm}$ TL and 681489 for a female of $66 \mathrm{~cm}$ TL.

Hence, in the three-end-point space defined in Winemiller and Rose (1992), hake should be placed somewhere resembling the periodic strategists. According to Rose et al. (2001) 'the longevity and high fecundity of periodic strategists should more than offset their low early survivorship, resulting in periodic strategists having the highest compensatory reserve' (i.e. the capacity of the population to offset variation in mortality), among the three life history strategies. Furthermore, as summarized in Cowan et al. (2000), 'High fecundities of fishes ensure high early life stage abundances that are subject to both density-independent controls responsible for variability in recruitment, and densitydependent regulation that stabilizes recruitment'.

Our results show that despite the large differences in recruit abundance between GSA 6 and the remaining GSAs from 1995 to 2003, the oscillations of condition in the various GSAs before 2009 ranged up and down the same basal level (overall mean). We hypothesize that the compensatory reserve of hake in that period of not heavily depleted spawner population was enough to ensure high early life stage abundance in all GSAs, and thus high densities of individuals at the early stage of recruitment. At the beginning of this stage, densities would be above the carrying capacity of each GSA. Therefore, density-dependent mortality rates would affect the population, either directly due to competition for food or indirectly due to density-dependent growth caused by that competition, which would extend the small-size stages which are more exposed to predation (Cowan et al. 2000, Lorenzen 2008). Mortality rates would remain high, gradually reducing the population of recruits until competition for food was relaxed and individuals would be able to forage enough to achieve a basal (minimum) condition, allowing them to survive and grow. The basal condition found for all GSAs despite their differences in recruit abundance supports this hypothesis and suggests that density-dependent mortality rates are an important mechanism stabilizing hake recruitment to levels below or close to the carrying capacity of the ecosystem in populations that are not heavily exploited (i.e. not in recruitment overfishing). In GSA 6, when recruitment overfishing reduced the spawning stock, and consequently the early life stages and recruitment abundance (GFCM 2017; Fig. 7 ), the competition for food among recruits would have been lower and allowed individuals to achieve a better condition than in the remaining GSAs. The increasing trend in condition also suggests that fishing activity rather than unfavourable environmental conditions is the most likely cause of reduction in spawner population and recruitment abundance.

In fact, climatic variability would involve a favourable environmental scenario for hake in GSA 6 during the last few decades. WeMOi showed a significant decreasing trend, with all values in the negative phase from 2002. In GSA 6, the landings of fishing resources such as sardine and anchovy have been related to WeMOi variability (Martín et al. 2012), although for both species the correlation found was positive and, 


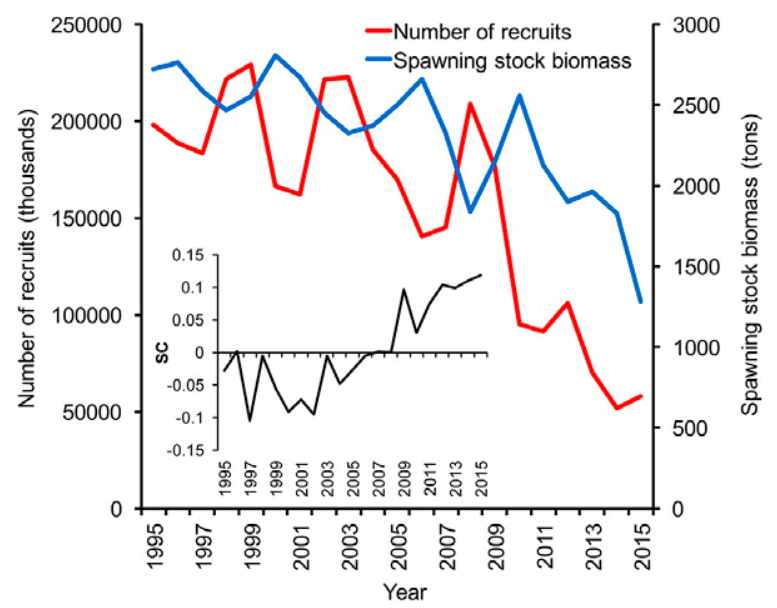

Fig. 7. - Hake recruitment and spawning stock biomass trends reported from the GFCM assessments in GSA 6 (GFCM 2017). The trend of the mean annual values of hake recruit somatic condition (SC) in GSA 6 is also shown.

with one year lag, contrary to that found in the present work: negative and direct (i.e. the condition of hake recruits was correlated with the WeMOi mean value of the previous 12 months). Positive WeMOi values are associated with higher runoff from the Ebre and Rhône rivers. This fact, along with the lower sea surface temperature and the predominance of northern winds, which result in strong wind mixing that also occurs in positive WeMOi phases, were considered favourable environmental conditions for the overall biological productivity in the northwestern Mediterranean. These conditions would explain the positive correlation with landings of sardine and anchovy in GSA 6, which are based on recruits of one-year-old individuals (Martín et al. 2012). On the other hand, torrential rainfall in the western Mediterranean is clearly linked to the negative phase of WeMOi (Martín-Vide and LópezBustins 2006). Moreover, extreme rainfall episodes seem to be increasing in frequency in the northwestern Mediterranean (Alpert et al. 2002), as would be expected from the decreasing trend of WeMOi. In the north of GSA 6, heavy rainfall and the associated terrestrial runoff have been reported to drive the coastal planktonic ecosystem from oligotrophy to a relative eutrophication that triggers phytoplankton responses, especially the increase in abundance of diatoms (Guadayol et al. 2009). This increase in primary production could ultimately increase the availability of trophic resources for hake recruits, mainly fast-growing, small-sized fishes such as gobids and small pelagics (Mellon-Duval et al. 2017), explaining the negative correlation found between condition and WeMOi. A strong positive correlation between hake recruitment and phytoplankton pigment concentration in the previous two months has already been reported in GSA 5 (Hidalgo et al. 2008), and was attributed to the subsequent enrichment of the trophic chain and the increase in trophic resources available for this species, pointing to a direct, non-delayed effect of increased primary production on hake recruits similar to that found in the present work in the adjacent GSA 6.
A negative correlation between the IDEA index and the abundance of recruits has already been reported in GSA 5, indicating that negative values of the IDEA index are related to favourable environmental conditions for hake recruitment (Massutí et al. 2008). These authors attributed it to a larger formation of Winter Intermediate Waters in the Gulf of Lions, which reach the northern continental shelf margin of the Balearic Islands in greater quantity, reinforcing the Balearic current and hence the productivity in this area. The IDEA index showed no trend during the period analysed and, thus, although it may have contributed to the inter-annual variability in hake recruit condition, it should not be expected to have contributed to the increasing trend detected in GSA 6. The general pattern of better condition in the westernmost GSAs detected in recent years may be a fishing effect, and the possibility that these GSAs are also suffering recruitment overfishing should be considered, particularly in GSA 7. In this area, next to GSA 6, and also an important area of hake recruitment in the western Mediterranean, SSB and recruitment also show sharp declining trends (GFCM 2017).

The main objectives of the research surveys at sea in the European Data Collection Framework is "to evaluate the abundance and distribution of stocks, independently of the data provided by commercial fisheries, and to assess the impact of the fishing activity on the environment" [Article 12, Council regulation (EC) $\left.\mathrm{N}^{\circ} 199 / 2008\right]$. Our results highlight the usefulness of survey data in stock assessment and the diagnosis of the exploitation status of fish resources. These data should be directly used in fisheries assessment rather than just as tuning datasets for virtual population analyses. However, the approach presented here will be appropriate only for species whose recruitment can be detected in coincidence with the surveys at sea. We have shown that weight and length data collected during fishery monitoring surveys can allow us to detect changes in the condition of the exploited resources. This simple morphometric data should be complemented, when possible, with other biological data such as liver weight, which better assesses the condition of species such as hake, because its liver stores most of its energy/lipid reserves (Lloret et al. 2012). We have demonstrated that condition may be a useful index for detecting recruitment overfishing, an exploitation state particularly difficult to diagnose. This has been the case for hake in GSA 6, where after years of decrease in SSB and recruitment, recruitment overfishing had not yet been diagnosed. The detection of this kind of overfishing is of paramount importance in stock assessment because failing to recognize it is one of the critical reasons that can lead to the collapse of a stock (Walters and Maguire 1996).

\section{ACKNOWLEDGEMENTS}

The MEDITS surveys included in the present work have been co-funded by the Instituto Español de Oceanografía and the EU through the European Maritime and Fisheries Fund (EMFF) within the National 
Programme of collection, management and use of data in the fisheries sector and support for scientific advice regarding the Common Fisheries Policy. The authors wish to gratefully thank the CNR-IRBIM of Mazara del Vallo for providing data for GSA 16, and COISPA for providing data for GSA 10 and GSA 18.

\section{REFERENCES}

Abella A., Fiorentino F., Mannini A., et al. 2008. Exploring relationships between recruitment of European hake (Merluccius merluccius L. 1758) and environmental factors in the Ligurian Sea and the Strait of Sicily (Central Mediterranean). J. Mar. Syst. 71: 279-293. https://doi.org/10.1016/j.jmarsys.2007.05.010

Adams P.B. 1980. Life history patterns in marine fishes and their consequences for fisheries management. Fish. Bull. 78: 1-12.

Alpert P., Ben-Gai T., Baharad A., et al. 2002. The paradoxical increase of Mediterranean extreme daily rainfall in spite of decrease in total values. Geophys. Res. Lett. 29: 311-314. https://doi.org/10.1029/2001GL013554

Barnston A.G., Livezey R.E. 1987. Classifications, seasonality, and persistence of low-frequency atmospheric circulation patterns. Mon. Weather Rev. 115: 1083-1126.

https://doi.org/10.1175/1520-0493(1987)115<1083:CSAPOL > 2.0.CO;2

Bartolino V., Colloca F., Sartor P., et al. 2008. Modelling recruitment dynamics of hake, Merluccius merluccius, in the central Mediterranean in relation to key environmental variables. Fish. Res. 92: 277-288. https://doi.org/10.1016/j.fishres.2008.01.007

Behrendt S. 2014. Im.beta: Add Standardized Regression Coefficients to lm-Objects. R package version 1.5-1. https://CRAN.R-project.org/package $=1 \mathrm{~m}$. beta

Bertrand J., De Sola L., Papaconstantinou C., et al. 2002. The general specifications of the MEDITS surveys. Sci. Mar. 66: 9-17. https://doi.org/10.3989/scimar.2002.66s29

Cowan J.H., Rose K.A., DeVries D.R. 2000. Is density-dependent growth in young-of-the-year fishes a question of critical weight? Rev. Fish Biol. Fish. 10: 61-89. https://doi.org/10.1023/A:1008932401381

Domínguez M.R. 2006. Study of reproductive potential of Merluccius merluccius in the Galician shelf. $\mathrm{PhD}$ thesis, Univ. Vigo, $288 \mathrm{pp}$.

Dremière P.Y., Fiorentini L., Cosimi G., et al. 1999. Escapement from the main body of the bottom trawl used for the Mediterranean international trawl survey (MEDITS). Aquat. Living Resour. 12: 207-217. https://doi.org/10.1016/S0990-7440(00)88471-5

Dutil J.D., Lambert Y. 2000. Natural mortality from poor condition in Atlantic cod (Gadus morhua). Can. J. Fish. Aquat. Sci. 57: 826-836. https://doi.org/10.1139/f00-023

El Habouz H., Recasens L., Kifani S., et al. 2011. Maturity and batch fecundity of the European hake (Merluccius merluccius, Linnaeus, 1758) in the eastern central Atlantic. Sci. Mar. 75: 447-454. https://doi.org/10.3989/scimar.2011.75n3447

Fiorentini L., Dremière P.Y., Leonori I., et al. 1999. Efficiency of the bottom trawl used for the Mediterranean international trawl survey (MEDITS). Aquat. Living Resour. 12: 187-205. https://doi.org/10.1016/S0990-7440(00)88470-3

General Fisheries Commission for the Mediterranean (GFCM), 2014. Scientific Advisory Committee (SAC). Subcommittee on Stock Assessment (SCSA). Report of the Fifteenth Session. Bar, Montenegro, 3-4 February 2014. 42 pp.

General Fisheries Commission for the Mediterranean (GFCM). 2017. Scientific Advisory Committee (SAC). Working Group on Stock Assessment of Demersal Species (WGSAD). Rome, Italy, 13-18 November 2017. Final report. 70 pp.

Guadayol O., Peters F., Marrasé C., et al. 2009. Episodic meteorological and nutrient-load events as drivers of coastal planktonic ecosystem dynamics: a time-series analysis. Mar. Ecol. Prog. Ser. 381: 139-155. https://doi.org/10.3354/mens07939

Hayes J., Shonkwiler J. 2001.Morphometric indicators of body condition: worthwhile or wishful thinking? In: Speakman J. (ed.), Body Composition Analysis of Animals: A Handbook of Non- destructive Methods. Cambridge University Press, Cambridge, pp. 8-38.

https://doi.org/10.1017/CBO9780511551741.003

Hidalgo B., Massutí E., Moranta J., et al. 2008. Seasonal and short spatial patterns in European hake (Merluccius merluccius, L) recruitment process at the Balearic Islands (NW Mediterranean): the role of environment on distribution and condition. J. Mar. Syst. 71: 367-384. https://doi.org/10.1016/j.jmarsys.2007.03.005

Hilborn R. 2002. The dark side of reference points. Bull. Mar. Sci. 70: 403-408.

Hilborn R., Stokes K. 2010. Defining overfished stocks: have we lost the plot? Fisheries 35: 113-120. https://doi.org/10.1577/1548-8446-35.3.113

Lloret J., Faliex E., Shulman G.E., et al. 2012. Fish health and fisheries, implications for stock assessment and management: the Mediterranean example. Rev. Fish. Sci. 20: 165-180. https://doi.org/10.1080/10641262.2012.695817

Lloret J., Shulman G., Love R.M. 2014. Condition and health indicators of exploited marine fishes. Wiley Blackwell, Chichester, $247 \mathrm{pp}$. https://doi.org/10.1002/9781118752777

López-Bustins J.A. 2007. L'Oscil-lació de la Mediterrània Occidental i la Precipitació als Països Catalans. PhD thesis, Univ. Barcelona, $400 \mathrm{pp}$.

Lorenzen K. 2008. Fish population regulation beyond "stock and recruitment": the role of density-dependent growth in the recruited stock. Bull. Mar. Sci. 83: 181-196.

MacArthur R., Wilson E.O. 1967. The theory of island biogeography. Princeton Univ. Press, Princeton, New Jersey, 203 pp.

Martín P., Sabatés A., Lloret J., et al. 2012. Climate modulation of fish populations: the role of the Western Mediterranean Oscillation (WeMO) in sardine (Sardina pilchardus) and anchovy (Engraulis encrasicolus) production in the north-western Mediterranean. Clim. Chang. 110: 925-939. https://doi.org/10.1007/s10584-011-0091-z

Martín-Vide J., Lopez-Bustins J.A. 2006. The western Mediterranean oscillation and rainfall in the Iberian peninsula. Int. J. Climatol. 26: 1455-1475. https://doi.org/10.1002/joc.1388

Massutí E., Monserrat S., Oliver P., et al. 2008. The influence of oceanographic scenarios on the population dynamics of demersal resources in the western Mediterranean?: Hypothesis for hake and red shrimp off Balearic Islands. J. Mar. Syst. 71: 421-438. https://doi.org/10.1016/j.jmarsys.2007.01.009

Mehault S., Domínguez-Petit R., Cerviño S, et al. 2010. Variability in total egg production and implications for management of the southern stock of European hake. Fish. Res. 104: 111-122. https://doi.org/10.1016/j.fishres.2010.03.019

Mellon-Duval C., de Pontual H., Métral L., et al. 2009. Growth of European hake (Merluccius merluccius) in the Gulf of Lions based on conventional tagging. ICES J. Mar. Sci. 67: 62-70. https://doi.org/10.1093/icesjms/fsp215

Mellon-Duval C., Harmelin-Vivien M., Métral L., et al. 2017. Trophic ecology of the European hake in the Gulf of Lions, northwestern Mediterranean Sea. Sci. Mar. 81: 7-18. https://doi.org/10.3989/scimar.04356.01A

Monserrat S., López-Jurado J.L., Marcos M. 2008. A mesoscale index to describe the regional ocean circulation around the Balearic Islands. J. Mar. Syst. 71: 413-420. https://doi.org/10.1016/j.jmarsys.2006.11.012

Morgan M.J. 2004. The relationship between fish condition and the probability of being mature in American plaice (Hippoglossoides platessoides). ICES J. Mar. Sci. 61: 64-70. https://doi.org/10.1016/j.icesjms.2003.09.001

Myers R.A., Rosemberg A.A., Mace P.M., et al. 1994. In search of thresholds for recruitment overfishing. ICES J. Mar. Sci. 51: 191-205. https://doi.org/10.1006/jmsc.1994.1020

Nakatsuka S., Ishida Y., Fukuda H., et al. 2017. A limit reference point to prevent recruitment overfishing of Pacific bluefin tuna. Mar. Policy 78: 107-113. https://doi.org/10.1016/j.marpol.2017.01.017

Oliver P. 1993. Analysis of fluctuations observed in the trawl fleet landings of the Balearic Islands. Sci. Mar. 57: 219-227.

Palutikof J.P. 2003. Analysis of Mediterranean climate data: Measured and modeled. In: Bolle H.J. (ed), Mediterranean Climate: Variability and Trends. Springer, New York, pp. 125-132. https://doi.org/10.1007/978-3-642-55657-9_6 
R Core Team. 2017. R: A language and environment for statistical computing. R Foundation for Statistical Computing, Vienna, Austria. https://www.R-project.org/

Recasens L., Chiericoni V., Belcari P. 2008. Spawning pattern and batch fecundity of the European hake (Merluccius merluccius (Linnaeus, 1758)) in the western Mediterranean. Sci. Mar. 72: 721-732. https://doi.org/10.3989/scimar.2008.72n4721

Restrepo V. 1999. Annotated Glossary of Terms in Executive Summary Reports of the International Commission for the Conservation of Atlantic Tunas' Standing Committee on Research and Statistics (SCRS). ICCAT, Madrid, Spain, 23 pp.

Rose K.A., Cowan J.H, Winemiller K.O., et al. 2001. Compensatory density dependence in fish populations: importance, controversy, understanding and prognosis. Fish Fish. 2: 293-327. https://doi.org/10.1046/j.1467-2960.2001.00056.x

Sainsbury K.J., Polacheck T.W. 1993. The use of biological reference points for defining recruitment overfishing, with an application to southern bluefin tuna. In: Hancock D.A. (ed.), Population dynamics for fisheries management, Australian Society for Fish Biology Workshop Proceedings. Australian Society for Fish Biology, Perth, pp. 265-274.

Sánchez R., Sánchez F., Gil J. 2003. The optimal environmental window that controls hake (Merluccius merluccius) recruitment in the Cantabrian Sea. ICES Mar. Sci. Symp. 219: 415-417.

Scientific, Technical and Economic Committee for Fisheries (STECF). 2015. Standardization procedures for data preparation, stock assessment methods and estimate of MSY reference points for Mediterranean stocks (STECF-15-11). Publications Office of the European Union, Luxembourg, 104 pp.
Scientific, Technical and Economic Committee for Fisheries (STECF). 2017. Mediterranean Stock Assessments - Part 2 (STECF-17-15). Publications Office of the European Union, Luxembourg, $663 \mathrm{pp}$.

Scientific, Technical and Economic Committee for Fisheries (STECF). 2018. Mediterranean Stock Assessments - Part 1 (STECF-18-12). Publications Office of the European Union, Luxembourg, $623 \mathrm{pp}$.

Sissenwine M.P., Shepherd G. 1987. An alternative perspective on recruitment overfishing and biological reference points. Can. J. Fish. Aquat. Sci. 44: 913-918. https://doi.org/10.1139/f87-110

Skjæraasen J.E., Nash R.D.M., Korsbrekke K., et al. 2012. Frequent skipped spawning in the world's largest cod population. Proc. Natl. Acad. Sci. U.S.A. 109: 8995-8999. https://doi.org/10.1073/pnas.1200223109

Walters C., Maguire J.J. 1996. Lessons for stock assessment from the northern cod collapse. Rev. Fish. Biol. Fish. 6: 125-137. https://doi.org/10.1007/BF00182340

Watanabe Y., Zenitani H., Kimura R. 1995. Population decline of the Japanese sardine Sardinops melanostictus owing to recruitment failures. Can. J. Fish. Aquat. Sci. 52: 1609-1616. https://doi.org/10.1139/f95-154

Winemiller O., Rose K.A. 1992. Patterns of life-history diversification in North American fishes: irnplications for population regulation. Can. J. Fish. Aquat. Sci. 49: 2196-2218. https://doi.org/10.1139/f92-242

Wood S.N. 2006. Generalized Additive Models: An Introduction with R. Chapman and Hall/CRC, London, 476 pp. 